\title{
Pastoral Visits to Presurgical Patients
}

\section{DONALD DAMSTEEGT}

While making my daily calls on presurgical patients, I visited Mrs. A. She was lying on the bed, knitting, and greeted me with a weak "hi." This was the first time I had met Mrs. A and our conversation started off with some light comments. I soon noticed that she was trembling and seemed to be experiencing a lot of inner turmoil, so I pulled up a chair and sat down. I stayed with her about half an hour during which she cried, we talked, and we prayed. When I left she seemed much calmer and she assured me that she could now face her surgery the next day with greater equanimity.

I mention Mrs. A to illustrate a basic tenet in the philosophy of the Department of Pastoral Care and Education at Bryan Memorial Hospital. If a pastor makes himself available to a patient, especially a patient under the stress of impending surgery, he may be able to perform a valuable therapeutic function. Not everyone wants to use a pastor's services, but if the pastor is open and available as a person, he will be useful to most pre-surgical patients. A patient may not always be aware that a problem exists, but he often will share some of his concerns if a pastor is available and his responses are appropriate.

Being available as a person and making appropriate responses is a skill which comes as a gift to a few but which any pastor can develop by being aware of his own and others' feelings and by reflecting on his pastoral contacts. First, I would like to discuss several typical reactions to surgery and how a pastor can be helpful in dealing with them. Then I shall explore two theoretical roles for the pastor working among hospital professionals in making pre-surgical calls.

For most people surgery is an emotionally stressful event. Surgery means coming to the hospital, leaving a pattern of everyday living, and giving up control of our bodies and even our lives. We choose or are forced to become dependent on other people, and we have to trust that they will see us through the pain and danger of sickness. Irving Janis, in his study of the psychological stress involved in surgery, uses this general theoretical postulate:

In adult life, exposure to any signs of potential mutilation or annihilation will tend to reactivate the seemingly outgrown patterns of emotional response which had originally been elicted and reinforced during the stress episodes of early childhood. ${ }^{1}$

In other words, when as adults we face surgery or any threat of harm, we will usually react as we did as children to fearful situations. It is not the purpose of this paper to try to spell out all the various forms this regression takes, but I do want to mention three typical reactions to surgery and then add a footnote about dealing with fear.

Probably the most common response to the threat involved in surgery is denial. We can deny the seriousness of our situation, the amount of pain that will be involved, we can even deny that the surgery will take place at all. Although this last is not com- 
mon once the person is in the hospital for surgery, it is common in people who don't feel well, but don't go to their doctor for help.

Denial, ultimately, is not a helpful response to threat, however. It serves only to hold fear temporarily in check and the fear returns fullblown whenever, "external cues momentarily prevent the person from being convinced that he is unaffected by the danger." "2 Nevertheless, everyone uses denial to some extent when the threat of surgery is faced. There are of course, different reasons why a person would deny the severity of his surgery or the severity of its effects. One reason is simply that he doesn't have all the facts the doctor has and another is his fear of the whole business.

The pastor can probably best be supportive with this kind of person. A pastor should not try to strip a person of his denial, but he should stay with reality as best he knows it and should communicate his willingness to share the person's fears. The pastor is not in a position to teach the patient the facts of his surgery; however, he can be with the patient as a person and can point to the greater presence of God as well.

A second common response to the threat of surgery is to unconsciously relate the threat of surgery to the threat of parental punishment in childhood. Thus the person facing surgery will "strive to mitigate his fate in the same way that, as a child, he succeeded in mitigating the parents' punishment, primarily by controlling his aggression and by making sure that he gives no cause for provoking the maximum penalty." 3 The result is that people who are facing surgery will be careful to be pleasant, if at all possible, to these in control.

This results in a number of things. The pre-surgical patient will probably be holding in a lot of emotion. There is the trauma of being in the hospital plus the fear that there is danger ahead, but yet the patient feels he must not make anyone angry at him. Often we find him smiling at all the nurses and doctors and assuring them that he is alright. Of course, this is a generalization which is not always true, but I believe most pre-surgical patients are afraid that they might alienate an important person if they show their anger or fear before surgery. Thus pre-surgical patients usually relate to important people as they did to their parents in childhood when punishment was threatened.

Important people here might be almost anyone. The pre-surgical patient would not want to alienate the nurse who has to take care of him; he certainly does not want to alienate his doctor who will be operating on him; and neither does he want to alienate his family and friends who are important sources of emotional support in the patient's helpless position. So the patient is left with a load of anger, fear, and frustration with which he does not know how to deal.

The pastor in this case can be a very helpful person. The pastor who is sensitive to the turmoil within the patient and who assures the patient of the pastor's unconditional acceptance, will give the patient a chance to express some of his negative feelings and thus regain a bit of adult equilibrium. In this case the pastor can help the patient break out of his helpless fear, a feat which often grips people in new and threatening situations. A hearty ventilation of anger and fear is the best way to regain adult control.

Another aspect of this same response is the pre-surgical patient's desire to 
confess his sins. A part of the unconscious way the patient tries to appease the authorities (parent surrogates, hospital personnel, God), whom the patient perceives as having control over him, is to confess his sins and ask for forgiveness. Usually the confessed sins are not objectively related to the surgery but are the result of unresolved and often neurotic guilt, as well as being related to a childhood pattern of confessing to avoid the maximum penalty. The pastor can provide a valuable function by hearing these confessions and assuring the pre-surgical patient of God's forgiveness and protection plus the assurance of his own continued concern and acceptance.

A third common response to impending surgery is to try to find some compensatory gains in having surgery. A person facing surgery will try to find some good aspects of it that will compensate for the pain and inconvenience involved. Another way of saying this is the colloquial advice to, "look for a silver lining in every cloud." Thinking of these compensatory gains helps the patient to see himself as an "active participant" in his fate rather than as a "passive victim." If a person is an active participant in his fate, he can see good in the future much more readily than if he sees himself as helpless.

A corollary to the tendency to look for compensatory gains is the tendency to review previous threat situations to find reassurance that the present threat can be mastered or to find steps to take in the present. If a person can see how he has handled something like this surgery before, he is much more likely to be able to accept it with confidence that he'll get better this time.

The pastor can be very helpful in his call on a pre-surgical patient if he can stimulate thinking about compensatory gains and past experience. This is especially true if the patient has been paralyzed by fear. Questions such as, "Can you see anything good in this," or "Have you ever run into a situation like this before," can have the effect of getting a person out of the circular thinking that fear sometimes produces. Thus, the pastor who is available as a person and who makes appropriate responses can often help a pre-surgical patient gain a whole new perspective on his surgery.

These then are three typical reactions to impending surgery. There are many other reactions listed by Janis and other writers, but these three I have seen in myself and others repeatedly. Probably the best way for a pastor to deal with any of the emotional reactions to stress is simply to be with the patient emotionally as best he can. Sophisticated knowledge of psychology is not necessary in order to make a helpful call on most people, but warmth and openness is. Thus, it is very important that the pastor be aware of his own feelings and be sensitive to the feelings of those he is hoping to help.

And now a footnote about fear, which is the dominant emotion experienced by pre-surgical patients. Many books and articles deal with reducing the patient's fear by instructing him in the details of what will happen in surgery and what he will experience after surgery. Hopefully, also, the pastor's visit will help to reduce the patient's fear through the pastor's encouragement and emphatic listening. But maybe fear in itself is not such a bad thing. 
Janis points out that a certain amount of fear is necessary prior to surgery or any threat situation in order to stimulate a "work of worrying." This work of worrying is similar to the work of mourning in helping a person adjust to painful reality. ${ }^{5}$ Janis contends that pre-surgical worrying is necessary in order for the patient to develop some "reality-based cognitions and expectations about opportunities for surviving the impending danger." ${ }^{6}$ These cognitions can then be self-delivered by the patient when he is actually suffering pain post-operatively. In other words, it is necessary realistically to rehearse what the surgery is going to mean in terms of pain, or loss, or change in life status.

Most people will automatically go through this work of worrying and the pastor can be most useful if he is as honest about the realities of the situation as he can be. However, there are people who seem to have no fear (probably because of denial) or people with extremely high fear (probably neurotic fear) with which the average pastor will not be trained to deal. In such cases possibly only a trained therapist would be able adquately to understand and work with the patient. Nevertheless, the pastor who comes as a supportive friend will be a help to most pre-surgical patients.

In the second section of this paper I would like to suggest two roles for the pastor as he makes his pre-surgical calls amid the professionals of the hospital. These are the roles of clown and priest. The pastor does not come to his pre-surgical calls as a medical authority; he does not come as a doctor or as a nurse who have technical details to give to the patient. Nor does he come as a trained psychotherapist, one who can sort out and deal with the traumatic memories and unconscious fears that are often released in the patient as a result of the loosening of his ego defences under the stress of impending surgery. However, I believe that there are two ways in which we can conceptualize how the pastor does come to his pre-surgical visits; these are as clown or priest.

The picture of the clown is one who comes as a human being among professionals. In the circus he is the one who plays the bumbling human among the superhuman feats of the other performers. The crowds respond with glee to his antics because they can identify with the clown much better than with the high wire experts or the lion tamer. The clown is one who represents the frailties in all of us, one to whom we could even confess our weaknesses and expect to be accepted. Further, the clown represents the real world. He is the one who has accidents and gets hurt and is embarrassed. He is the one who laughs and relaxes and is human, who is accepted for what he is rather than for what he does. So in some ways the clown is much more believable than the professionals.

Heije Faber, in his book Pastoral Care in the Modern Hospital, expands on the similarities of the clown in the circus to the pastor in the hospital. Faber says that there are three tensions with which the clown and the pastor live. "First, the tension between being a member of a team and being in isolation; secondly, the tension of appearing to be and feeling like an amateur among acknowledged experts; and finally, the tension between the need for study and training on the one hand and the necessity to be original and creative on the other." 7 
The pastor in the hospital is part of the healing team but he is also very much isolated. He may have good rapport with the nurses and even the doctors, but most of his work is done alone. He often has a symbolic rather than an active role. He symbolizes the outside world, the community with which the patient is familiar. He symbolizes the concern and support of God and the church. Finally, the pastor helps maintain perspective and a certain amount of subjectivity amid the objective "curefactory" atmosphere of the hospital.

The second tension the pastor lives with is being an amateur among acknowledged experts. He symbolizes the human element, the emotional element, the frail element in the midst of the sterile procedures. The other hospital personnel, from lab technicians to doctors, come to do something to the patient. The pastor comes to be $\mathrm{with}$ the patient. He is one who is so human that the patient can confess his own negative feelings. The pastor is the one who will accept the patient as a whole human being, not just a body or a disease classification.

But, the pastor is an amateur in that his tools are humanness and warmth rather than gadgets. This amateur status can lead to a feeling of inferiority at times, probably like the inferiority of the clown between the juggler and the trapeze artist. Yet the pastor in his humanness points to the wider perspective of the patient's past and future and thus helps the patient to transcend his present misery.

The third tension of the pastor is the need for study and training, but also creativity. Pastors have to study long and hard to be ordained, and then much looking inward is necessary before sensitivity can be added to knowledge. The clown is not really a bumbling idiot. He studies long and hard in order to perfect his act, and then new learning never stops. Yet the work of a good clown, or a good pastor, is that he will be able to respond creatively out of his "guts" when a new situation arises.

In most of his pre-surgical calls, the pastor comes as clown. He offers himself as a human being and as a symbol: a symbol of the outside world, of the patient's community, of the subjective aspects of life, and of God. The pastor comes, not with a metal instrument with which to probe the patient, but with an understanding of the tragic which makes it safe for the patient to share his weakness and fears. At times the pastor even becornes a clown in that he cheers people up with his laughter or his errors. So, in most of his pre-surgical calls the pastor is a clown.

But there is another role for the pastor and that role is priest. This is the role the pastor takes when he is specifically the representative of God or the church. This is the role he takes more often when people are seriously ill or are very upset. In comparison with the role of the clown, the role of priest is used less often. The hospital chaplain is likely to be a clown more often since he tries to be available to everyone. The parish minister is more likely to be a priest more often since he comes as the patient's personal pastor.

The role of priest is one in which the pastor stands between the patient and the subjective and ultimate elements in life. As a priest, the pastor hears the confession of those who have sinned, especially those who are afraid that God is punishing them for their sins. And, as a priest, the pastor mediates God's love and forgiveness to the patient who is confessing. As a priest, the pastor testifies to God's 
presence at the death bed and acts out God's presence by staying with the lonely person. Finally, as priest, the pastor gives sacraments, testifying in a more concrete way to the presence and forgiveness of God. Thus, the role of priest is a more restricted one than that of clown. The pastor is first the clown and then, when appropriate, he becomes the priest.

In terms of pre-surgical calls, the pastor will be used as priest by those who are more fearful. They will want prayer and assurance of God's protection. They will often confess their negative feelings or their past acts as sins to be forgiven in the present. This can be the result of the regression and greater dependency which hospitalization causes, regression which comes out as trying to appease God as a parent-surrogate. Or, it can be that the patient has a more childish faith. Either way, the pastor can perform a valuable therapeutic function by using the reassuring symbols of the patient's religious experiences in assuring him of God's protection.

Which of the two roles the pastor takes in his pre-surgical call should be determined by the patient. He comes to offer himself in the name of God to be used as the patient needs him. In the case of Mrs. A, who was mentioned at the beginning of this paper, I became a priest. I sat quietly with her as she cried and then I listened to her fears and her anger. She was afraid of other-wordly and irrational things and felt guilty for having these fears. Before I left, I prayed with her asking for God's protection and presence, and she responded with a prayer of her own. This seemed to help. She appeared to be much calmer and more able to face surgery the next day with equanimity because I had been available and was willing to become her priest. That same day I was a clown to the other seven pre-surgical patients I visited.

\section{FOOTNOTES}

${ }^{1}$ Irving L. Janis, Psychological Stress: Psychoanalytic and Behavioral Studies of Surgical Patients (New York: John Wiley and Sons, Inc., 1958), p. 196.

2 Ibid., p. 199.

${ }^{3}$ Ibid., p. 197.

Ibid., p. 198.

${ }^{5}$ Ibid., p. 375.

"Ibid.

${ }^{7}$ Heije Faber, Pastoral Care in the Modern Hospital (Philadelphia: Westminster Press, 1971), pp. 81, 82. 


\section{BIBLIOGRAPHY}

\section{BOOKS}

Cabot, Richard C., and Dicks, Russell L. The Ant of Ministering to The Sick. New York: Macmillan Co., 1959

Faber, Heije. Pastoral Care in the Modern Hospital. Philadelphia: Westminster Press, 1971

Janis, Irving L. Psychological Stress: Psychoanalytic and Behavioral Studies of Surgical Patients. New York: John Wiley and Sons, Inc., 1958

Mitchell, Kenneth R. Hospital Chaplain. Philadelphia: Westminster Press, 1972 Zinberg, Norman E. (ed.) Psychiary and Medical Practice in a General Hospital. New York: International Universities Press, Inc.. 1965

\section{JOURNALS}

Egbert, Lawrence D., et al. "Reduction of Postoperative Pain by Encouragement and Instruction", New England Joumal of Medicine, Vol. 270, No. 16(1964), pp. $825-27$

Giller, Donald W. "Some Factors in Recovery from Surgery", The OR (July 1963), pp. $83-85$

Healy, Kathryn M. “Does Preoperative Instruction Make a Difference?", American Journal of Nursing, Vol. 68, No. 1 (Jan. 1968), pp. 62-67

Hughes, Richard T. "Spiritual Crises Facing Surgical Patients", Pastoral Psychology (Dec. 1971) pp. 27-34

Lindeman, Carol A. and Stetzer, Steven L. "Effects of Preoperative Visits by Operating Room Nurses", Nursing Research, Vol. 22, No. 1 (Jan.-Feb. 1973), pp. $4-16$

Luke, Sister Mary O.S.F. "How the Operating Room Nurse Can Help to Personalize Patient Care", The Modern Hospital, Vol. 105, No. 6 (Dec. 1965), pp. $90-92$

Spielberger, Charles D., et al. "Emotional Reactions to Surgery", Journal of Consulting and Clinical Psychology, Vol. 40, No. 1 (1973) pp. 33-38

Stone, Ruth M. "Resolved: Preoperative Care", AORN Joumal, Vol. 13, No. 5 (May 1971) pp. 61-63

Weiler, Sister M. Cashel. "Postoperative Patients Evaluate Preoperative Instruction", American Journal of Nursing, Vol. 68, No. 7 (July 1968), pp. 1465-1467 